\title{
Prevalence of periodontal disease in dogs and owners' level of awareness - a prospective clinical trial ${ }^{1}$
}

\author{
Natalia Alves Fernandes ${ }^{2}$, Andréa Pacheco Batista Borges ${ }^{3}$, Emily Correna Carlo Reis ${ }^{3}$, \\ Rodrigo Viana Sepúlveda ${ }^{4}$ Kelly Cristine de Sousa Pontes ${ }^{3}$
}

\begin{abstract}
Periodontal disease (PD) is widely known among veterinarians for its high prevalence and serious consequences to the dogs. The objective of this study was to assess the occurrence of PD in dogs that live in the micro-region of Viçosa, treated at the Veterinary Hospital of the Federal University of Viçosa (HVT - Hospital Veterinário da Universidade Federal de Viçosa), as well as to assess how aware of this disease dog owners are. In order to do so, all dogs treated at the HVT from March 10th, 2009 to November 30th, 2009, on alternate days, had their oral cavities examined. Medical history data, such as age, type of food, main complaint and owner consent, halitosis, presence of dental calculus, inflammation and gingival recession and tooth loss, were collected. A prevalence of $88.67 \%$ was found for PD in dogs referred to the HVT, and $2.67 \%$ were referred due to this disease. Of all the owners who participated in the study, $43.83 \%$ knew about periodontal disease and of these $17.46 \%$ made use of some type of prevention or treatment. Therefore, periodontal disease is highly prevalent and the owners are not aware of the disease. Thus, a dog owner clarification program on periodontal disease is needed in the area where HVT-UFV operates.
\end{abstract}

Key words: canines, epidemiology, periodontics.

\section{RESUMO}

\section{Prevalência da doença periodontal em cães e ciência dos proprietários a respeito da doença}

A doença periodontal (DP) é amplamente conhecida pelos médicos veterinários por sua alta prevalência e graves conseqüências aos cães. Objetivou-se neste estudo avaliar sua ocorrência em cães da micro-região de Viçosa atendidos no Hospital Veterinário da Universidade Federal de Viçosa (HVT), assim como o grau de conhecimento dos proprietários em relação à doença. Para tanto, todos os cães atendidos no HVT no período de 10 de março de 2009 a 30 de novembro de 2009, em dias alternados, tiveram suas cavidades orais examinadas. Informações, abrangendo dados de anamnese como idade, tipo de alimentação, queixa principal e anuência do proprietário, halitose, presença de cálculo dentário, inflamação e recessão gengival e perda dentária foram colhidas. Observou-se uma prevalência de $88,67 \%$ para a DP em cães encaminhados ao HVT, sendo que 2,67\% foram encaminhados devido a essa doença. De todos os proprietários que participarem do estudo, 43,83\% conheciam a doença periodontal e, destes 17,46\% utilizavam alguma medida de prevenção ou tratamento. Portanto, a doença periodontal é de grande prevalência e os proprietários não estão cientes da doença. Com isso, torna-se necessário estabelecer um programa de esclarecimento dos proprietários de cães da região atendida pelo HVT-UFV quanto à doença periodontal.

Palavras-chave: caninos, epidemiologia, periodontia.

\footnotetext{
Received for publication on March $11^{\text {th }}, 2011$ and approved on June $12^{\text {th }}, 2012$.

Extracted for the first author scientific report presented to FAPEMIG/UFV.

2 Graduate student of veterinary medicine. Departamento de Veterinária da Universidade Federal de Viçosa, Avenida Peter Henry Rolfs, s/n, Campus Universitário, 36570-000, Viçosa, Minas Gerais, Brazil. naty_fernandes9@ hotmail.com

${ }^{3}$ Veterinarians, Doctor Science. Departamento de Veterinária da Universidade Federal de Viçosa, Avenida Peter Henry Rolfs, s/n, Campus Universitário, 36570-000, Viçosa, Minas Gerais, Brazil. andrea@ufv.br Bolsista de produtividade - CNPq (Author for correspondence); emilycarlo@yahoo.com.br; kellycpontes@yahoo.com.br

${ }^{4}$ Veterinarian. Departamento de Veterinária da Universidade Federal de Viçosa, Avenida Peter Henry Rolfs, s/n, Campus Universitário, 36570-000, Viçosa, Minas Gerais, Brazil. digosepulveda@hotmail.com
}

Rev. Ceres, Viçosa, v. 59, n.4, p. 446-451, jul/ago, 2012 


\section{INTRODUCTION}

Dentistry is a branch of Veterinary Medicine that has been growing and standing out on the world scenario. This may be the result of the increasingly importance of pets in people's lives and, consequently, associated with veterinarians being more concerned about the health of pets. For these reasons, it is possible to note that pets are living longer, and when they age, they tend to have chronic diseases such as the periodontal disease.

Periodontal disease (PD) refers to the inflammatory disease caused by pathogenic microflora in the biofilm or dental plaque that forms on the tooth, resulting in immune and inflammatory response that develops in the periodontal tissues, particularly the gum, the alveolar bone, the periodontal ligament and the cementum, reaching up to the loss of tooth supporting tissues (Harvey, 1998; Marreta, 2001). At first, this microflora is normal, reduced and predominantly consists of Gram positive, that are immobile and aerobic, and capable of adhering to the healthy surface of the tooth neck (Wiggs et al., 1998). When there is no regular cleaning, such as toothbrushing, these bacteria combine with salivary glycoproteins, polysaccharides, lipid, carbohydrate, water and the remnants of epithelial cells, leukocytes and macrophages, to form dental plaque. As the accumulation advances, bacteria begin to develop also into the gingival sulcus, giving rise to an inflammatory response that injures primarily the gingiva and the junctional epithelium, causing gingivitis to occur again (Dennison \& Van Dyke, 1997; Ohlrich et al., 2009).

Progressively, the epithelium is forced to increasingly move toward the root of the tooth, resulting in the formation of large contaminated spaces between the gum and the tooth surface, called periodontal pockets. Results of bacterial metabolism, enzymes produced by many bacteria in the periodontal pockets, as well as the periodontal patient inflammatory response itself, are causes of tissue injury (Reynolds \& Meikle, 1997). In periodontal pockets there is an accumulation of predominantly anaerobic mobile gram-negative bacteria, constituting a source of infection for the whole organism. As this disease advances, the cementum, the periodontal ligament and the alveolar bone are also injured and reabsorbed (Harvey, 1998, Wiggs et al, 1998). The end result of this disease is the loss of the teeth affected, resulting in functional difficulties for eating (Harvey, 1998; Accarini \& Godoy, 2006).

Teeth loss is not the only consequence of the PD, other very common consequence is the opening of the oral and nasal cavity, as a result of periodontal tissue severe loss, along the roots of maxillary canines and premolars. In this case, we note constant sneezing and mucopurulent discharge, and pulmonary complications may occur (Harvey, 1998, Wiggs et al.,, 1998). Pathological fractures of the mandible are also associated with PD, they occur due to alveolar bone resorption that significantly decreases its thickness, making it weak. These fractures are difficult to treat, because it is difficult to stabilize them, and also because of the very characteristics of the alveolar bone affected by the periodontal disease (Hale, 2002; Legendre, 2003).

Besides the damages it causes to oral health, PD is also relevant for systemic influences, relating to several diseases such as cardiovascular disease, diabetes, low birth weight, renal and pancreatic cancer. Similarly, PD is indicated as critical in the occurrence of many infections, since it is the source of bacteria that cause diseases such as arthritis, pneumonia, encephalitis, endocarditis, and glomerulonephritis (Cruz et al., 2005; Pihlstrom et al., 2005; Accarini \& Godoy, 2006, Michaud et al., 2008).

The treatment for periodontal disease requires an initial procedure called periodontal prophylaxis, which includes the removal of plaque by scaling and root planing, tooth polishing and irrigating the gingival sulcus region with $0.9 \%$ saline solution or $0.12 \%$ chlorhexidine solution (Harvey, 2005; Niemic, 2008). Other procedures may be required for the removal of plaque in periodontal pockets that are deeper than $5 \mathrm{~mm}$ and to attempt to regenerate periodontal defects (Grove, 1998; Marreta, 2001; Niemic, 2008).

Despite its significance, currently, the epidemiological data on the occurrence of PD are predominantly from the USA. Studies have indicated great prevalence of this disease, in a way that considering dogs that are older than five years, of all the diseases and injuries they may have, PD is the most common of all, estimated in $80 \%$ of the population (Harvey \& Emily, 1993). Only two studies conducted in Brazil have indicated the prevalence of $71.4 \%$ in a clinic located in São Paulo (Venturini et al., 2007) and 92.5\% in a veterinary hospital in Uberlândia (Milken et al., 2003). Thus, this present work aimed at gathering data on the prevalence of PD in the micro-region of Viçosa, at the Veterinary Hospital of the Federal University of Viçosa (HVT-UFV) as well as to assess how aware of this disease dog owners are, and use this information to support future preventive actions.

\section{MATERIALS AND METHODS}

This study was approved by the Ethics Committee of the Veterinary Department at the Federal University of Viçosa, Protocol No 06/2009. From March 10th, 2009 to November 30th, 2009, on randomly alternate days within this period, all dogs referred to the Screening department of the small animal Veterinary Hospital at the Federal University of Viçosa (HVT-UFV) were examined. 
The epidemiological survey form used was specially created to collect the necessary data by means of an interview. Each dog owner was asked why they were bringing their dog to the hospital, about their dog's dental history, the type of feed they used for their dog, and if they were aware of PD in dogs, and if they were, what they knew about it.

Then, each animal was physically examined. The following parameters were assessed: asymmetric head, size of sub-mandibular lymph nodes, mucosa color, presence of halitosis, presence and location of dental calculus, gingival inflammation, assessed by the presence of redness and swelling, evident gingival recession, spontaneous gingival bleeding, furcation exposure; oronasal fistula, skin fistulas, pus and tooth loss. Each of these parameters was described in detail. The level of periodontal disease severity for each animal was scored according to Table 1, adapted from Harvey \& Emily (1993).

After the consultation, clinical examination and completion of the case, additional tests, treatments and final diagnosis of each patient were obtained from the hospital's routine medical records.

Data of all patients were summarized in a single base spreadsheet for analysis: pet name, medical record number, species, breed, age, weight, feed, main complaint, consent of the owner as to PD, PD control measures, degree of PD, and final diagnosis.

The prevalence of PD was calculated by dividing the total number of positive cases (numerator) by the total number of patients examined (denominator) and then multiplying by 100 . For other data, descriptive statistics were used.

\section{RESULTS AND DISCUSSION}

A total of 343 animals were examined from March 10th, 2009 to November 30th, 2009. All dogs brought to the department of Clinics and Surgery and Small Animal of the Veterinary Hospital at the Federal University of Viçosa in the days of the study were included.

\section{General distribution of PD}

Of the 343 animals, 39 did not have the disease or had only gingivitis, 162 had mild PD, 94 moderate and 48 had severe PD (Figure 1). Thus, the prevalence of PD was $88.67 \%$. This finding is consistent with similar studies conducted in Brazil, more specifically in São Paulo and Uberlândia, who reported prevalences of 71.4 (Venturini et al., 2007) and $92.5 \%$ (Milken et al., 2003), respectively. However, in these studies, dog clinical examination was performed under general anesthesia, which is ideal to assess the accurate degree of PD, particularly with regard to the evaluation of the degree of furcation exposure and the occurrence of oronasal fistula. In this study, clinical examination was conducted with the animals on stationary position, with no sedative effect. Thus, these two parameters may have been underestimated, since they require probing the gingival sulcus, and this procedure may only be performed with animals under general anesthesia (Harvey, 1998; Marreta, 2001). However, as an advantage, we have a more diverse population than those of the previous studies, animals that were not always taken to the veterinarian for specific problems in their oral cavity.

The main complaints, or the reasons why the owners took their dogs to the HVT, differed quite a lot, they included trauma with wounds and orthopedic injuries, different systemic diseases that were infectious or not, and localized conditions, such as skin lesions and ophthalmic conditions. Of these, only $2.67 \%$ of the cases had PD as their main complaint, ie, the owner had brought their animals to HVT looking for information and / or treatment for PD.

That being said, it is alarming that $88.67 \%$ of the animals needed treatment for PD, and only $2.67 \%$ had been brought to HVT for that reason. Gum disease is still a stage where treatment can fully recover the supporting tissues of the teeth, therefore, it is said to be "reversible." However, treatment for PD in dogs, so far, is acknowledged as irreversible, because there is no technique included in clinical routine to restore lost periodontal tissues (Groove, 1998, Wiggs et al., 1998; Christgau et al., 2007). Figure 1 shows that $47.33 \%$ of animals had mild PD, and periodontal prophylaxis was the recommended treatment, since in this initial stage there is a possibility of recovering the periodontal tissues to a level close to that of healthy periodontum (Groove 1998; Niemic, 2008). However, $41.33 \%$ of the animals had already lost their supporting

Table 1. Classification of animals treated at the Veterinary Hospital of the Federal University of Viçosa and according to the occurrence and severity of periodontal disease (PD) from March 10th to November 30th, 2009

\begin{tabular}{lll}
\hline Degree & Classification & Parameters \\
\hline 1 & No disease or gengivitis & When dog did not have PD \\
2 & Mild & Gingival redness, swelling of the gums, receding gums and halitosis \\
3 & Moderate & Frontal teeth with exposed tooth root, spontaneous bleeding of gums and tooth loss \\
4 & Severe & Frontal teeth with any of the following: furcation exposure, purulent discharge, oronasal \\
& & fistula and fistulation to the skin. \\
\hline
\end{tabular}


tissues in a more advanced stage, and thus required more advanced procedures, such as making mucoperiosteal flap for adequate removal of dental plaque in the pockets, gingivoplasty or gingivectomy procedures to reduce pockets, and surgeries such as dental extractions and correction of mucoperiosteal advancement flaps to correct oronasal fistures (Groove, 1998, Marreta 2001; Legendre, 2003; Niemic, 2008).

Further, the level of dog owner awareness regarding the existence of PD in dogs was examined, and it was found that $43.83 \%$ of them were aware of this disease. Of these, only $17.46 \%$ are concerned to carry out any procedure for the prevention of $\mathrm{PD}$, such as regular tooth brushing or periodontal prophylaxis performed by a veterinarian. Since $88.67 \%$ of the animals need treatment, it is alarming that only about half of their owners knew that their dogs were susceptible to this disease, and also, only a small part of them were doing some type of disease prevention. Even when several studies have shown that the consequences of PD are severe and bring great harm to animal health, including diseases of the oral cavity as damage to oral health, such as loss of teeth and the occurrence of oronasal fisture and pathological fractures of the mandible (DeBowe et al., 1996; Legendre, 2003). The relevance of PD also adresses systemic influences, widely studied in humans, which are related or may aggravate several health conditions, such as cardiovascular disease, diabetes, low birth weight, pancreatic and kidney cancer and different types of diseases where infection originates from PD microorganisms; for instance, arthritis, pneumonia, encephalitis and glomerulonephritis (Antunes et al., 2003; Pihlstromet al., 2005; Accarini \& Godoy, 2006; Michaud et al., 2008; Pavlica, et al., 2008).

\section{Breed distribution}

The main dog breeds addressed in this study are shown in Figure 2. Most animals had no breed defined

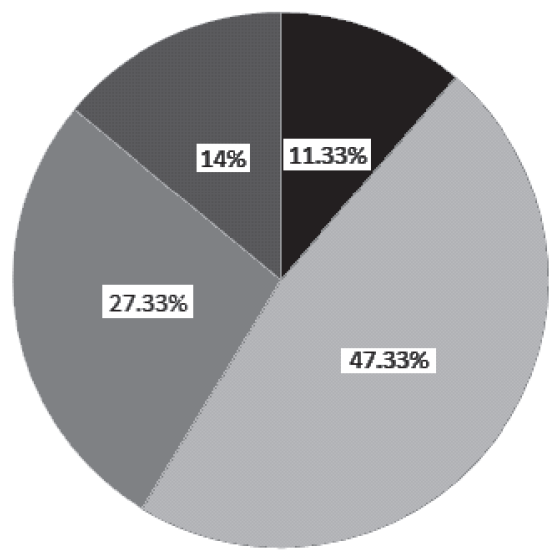

(NBD, no breed defined), followed by Poodles, in accordance with Paranhos (2001) in São Paulo. It can be noted that, generally, most of them were small breed animals (poodle, teckel, pinscher, Brazilian terrier and Yorkshire terrier), totaling $42.4 \%$. It was not possible to establish predisposing breeds to PD, since the number of animals in the study for such analysis was insufficient. However, the prospective study was chosen to eliminate errors of variations in the classification of PD, lack of standardization of nomenclature and failures when completing forms, as mentioned by Venturini (2006).

\section{Weight Distribution}

The weight of the dogs tested varied significantly as shown in Table 2, by mean and standard deviation of $11.37 \pm 9 \mathrm{~kg}$, and also by minimum weight of 2.0 and maximum of $45.0 \mathrm{~kg}$. In canines, size and consequently weight differ significantly because of the large number of different breeds, categorized from small to giant, and PD affects all of them (Harvey, 1998; Milken et al., 2003; Venturini, et al., 2007). There is still considerable variation in the weight of the animals within a breed, mainly due to obesity, increasingly more common in small breeds (Venturini, 2006).

\section{Feed}

Dog feeding ranged from chow diet (47.3\%), chow with food $(50.3 \%)$ and only food $(2.1 \%)$. Similarly to the distribution of breeds, it was not possible to establish a correlation between the type of food animals ate and the occurrence or severity of PD, since the number of animals in the study for such analysis was insufficient. It is noteworthy that this result may be influenced by the wide variation in type and frequency with which the animals were given complementary food. Ilga $\bullet$ s B Birgele (2003) have observed that oral cavity diseases are more frequent in animals that are not fed with chow, but with homemade food instead. These authors emphasized the
- Degree 1 - No disease or gengivitis

Degree 2 - Mild PD

Degree 3 - Moderate PD

Degree 4 - Severe PD

Figure 1. Distribution of periodontal disease (PD) degree of dogs referred to the Veterinary Hospital of the Federal University of Viçosa from March 10th to November 30th, 2009. 


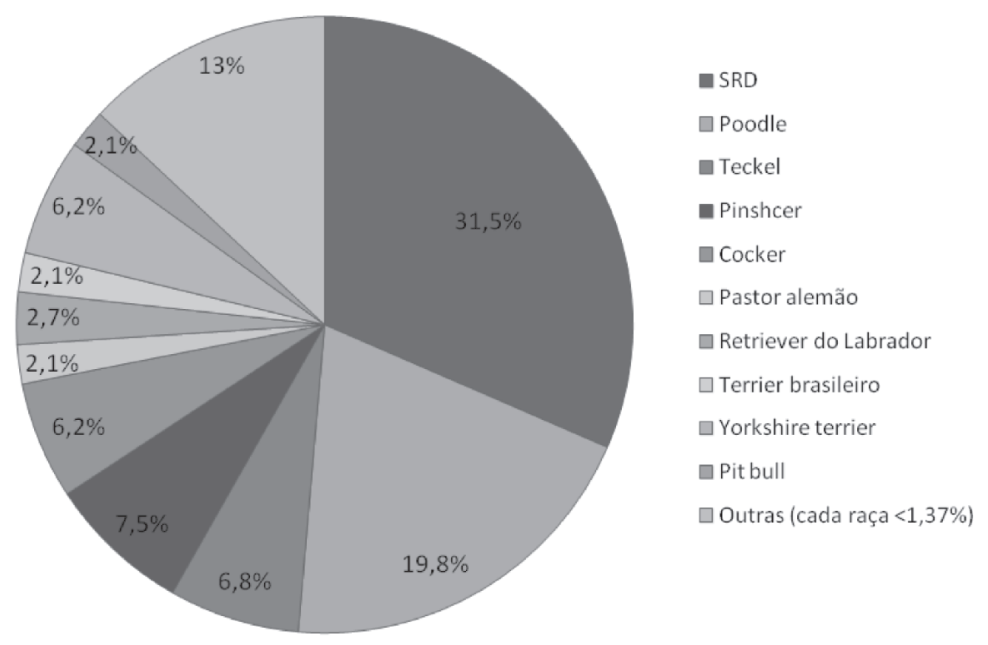

Figure 2. Most breeds of dogs referred to the Veterinary Hospital of the Federal University of Viçosa from March 10th to November 30th, 2009.

Table 2. Weight median, mean and standard deviation of dogs referred to the Veterinary Hospital of the Federal University of Viçosa from March 10th to November 30th, 2009, in relation to the degree of PD

\begin{tabular}{lcccc}
\hline \multirow{2}{*}{ Weight } & \multicolumn{4}{c}{ Degree of PD } \\
\cline { 2 - 5 } & $\mathbf{1}$ & $\mathbf{2}$ & $\mathbf{3}$ & $\mathbf{4}$ \\
\hline Mean and standard deviation & $8.58 \pm 6.96$ & $12.72 \pm 10.03$ & $11.78 \pm 8.8$ & $7.93 \pm 5.28$ \\
Median & 6.57 & 8,7 & 7.9 & 6 \\
\hline
\end{tabular}

Degree 1 - No disease or gengivitis; Degree 2 - Mild PD.; Degree 3 - Moderate PD.; Degree 4 - Severe PD.

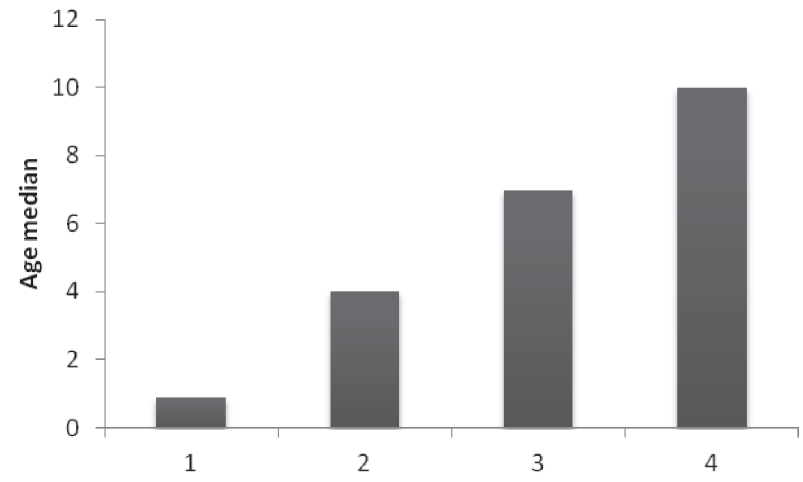

Figure 3. Age median of dogs referred to the Veterinary Hospital of the Federal University of Viçosa from March 10th to November 30th, 2009, in relation to the degree of PD.

possibility that the mechanical action of solid chow may help remove dental plaque, and thus aid to lower the frequency of PD in animals fed that way, due to the lower occurrence of PD.

\section{Age associated with degree of $P D$}

A tendency to increased degree of PD was associated with increasing animal age when analyzing both the median (Figure 3) and mean and standard deviation (Figure 4). Previous studies have also demonstrated such trend, which is largely due to lack of preventive actions and / or

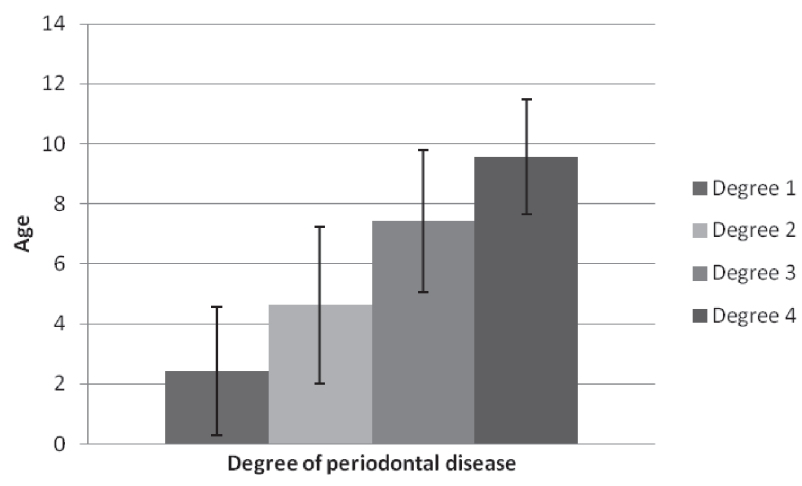

Figure 4. Age mean and standard deviation of dogs referred to the Veterinary Hospital of the Federal University of Viçosa from March 10th to November 30th, 2009, in relation to the degree of PD.

treatment of PD, since it is a condition that involves the accumulation of dental plaque and progressive resultant lesions (Harvey, 1998; Wiggs et al., 1998), and it is, therefore, advancing and irreversible.

\section{CONCLUSION}

Given the conditions of this study, we may conclude that the population of dogs brought to HVT had $88.67 \%$ prevalence of periodontal disease, and only $2.67 \%$ had been referred to the hospital because of this disease. Of all the dog owners who participate in the study, only 
$43.83 \%$ were aware of periodontal disease, and only $17.46 \%$ of these were taking some measure of prevention or treatment for it. This shows that dog owners are not aware of how relevant PD can be to the health of their animals. Thus, the factors of high prevalence of periodontal disease and little awareness of dog owners, found in this study, clearly show a need for a program that will give light to the matter of PD in the area where HVT operates, including its occurrence, consequences, treatment, prevention and other guidelines.

\section{ACKNOWLEDGEMENTS}

The authors thank FAPEMIG for the scientific initiation scholarship granted to the first author, for the $\mathrm{PhD}$ scholarship granted to the third author, and give thanks to $\mathrm{CNPq}$ for funding the project.

\section{REFERENCES}

Accarini R \& Godoy, MF (2006) DP como potencial fator de risco para síndromes coronarianas agudas. Arquivo Brasileiro de Cardiologia, 87:592-596.

Antunes FS, Graça MA, Nurkim NL \& Oliveira RB (2003) Diabetes mellitus e a doença periodontal. Revista Odonto Ciência, 18:107-111.

Christgau M, Caffesse Rg, Schmalz G \& D'souza, RN (2007) Extracellular matriz expression and peirodontal wound-healing dynamics following guided tissue regeneration therapy in canine furcation defects. Journal of Clinical Periodontology, 34:691708

Cruz SS, Costa MCN, Gomes Filho IS, Vianna MIP \& Santos CT (2005) Maternal periodontal disease as a factor associated with low birth weight. Revista de Saúde Pública, 39:782-787.

Debowe LJ, Mosier D, Logan E, Harvey CE; Lowry S \& Richardson DC (1996) Association of periodontal disease and histologia lesions in multiple organs from 45 dogs. Journal of Veterinary Dentistry, 13:57-60.

Dennison DK \& Van Dyke TE (1997) The acute inflammatory response and the role of phagocytic cells in periodontal health and disease. Periodontology 2000, 14:54-78.

Grove TK (1998) Treatment of periodontal disease. Veterinary Clinics of North America: Small Animal Practice, 28:11471167.

Hale, FA (2002) Management of bilateral, pathologic, mandibular fractures in a dog. Journal of Veterinary Dentistry, 19:22-24.

Harvey CE \& Emily PP (1993) Small animal dentistry. 1ed. St. Louis, Mosby. p.413.

Harvey CE (1998) Periodontal disease in dogs: Etiopathogenesis, prevalence, and significance. Veterinary Clinics of North America: Small Animal Practice, 28:1111-1128.

Harvey CE (2005) Management of Periodontal Disease: Understanding the Options. Veterinary Clinics of North America: Small Animals, 31:819-836.

Ilga $\bullet$ A \& Birgele E (2003) Correlation between the condition of the mouth cavity and food in different breed of dogs. Veterinarija ir zootechnika, 21:43.

Legendre, L (2003) Intraoral acrylic splints for maxillofacial fracture repair. Journal of Veterinary Dentistry, 20:70-78.
Marreta SM (2001) Recognition and Treatment of Periodontal Disease. In: Proceedings of the Atlantic Coast Veterinary Conference, New Jersey. 2001.

Michaud DS, Liu Y, Meyer M, Giovannucci E \& Joshipura K (2008) Periodontal disease, tooth loss, and cancer risk in male health professionals: a prospective cohort study. Lancet Oncology, 9:550-558.

Milken VMF, Silva FOC, Rezende RJ \& Lima TBF (2003) Prevalência de cálculo dental em cães no município de Uberlândia. Minas Gerais. Arquivos de Ciências Veterinárias e Zootecnia da UNIPAR, 6:57-60.

Niemic BA (2008) Periodontal Therapy. Top Companion Animal Medicine, 23:81-90.

Ohlrich EJ, Cullinan MP \& Seymou GJ (2009) The immunopathogenesis of periodontal disease. Australian Dental Journal, 54:S2-S10.

Paranhos NT (2001) Estudo das populações canina e felina em domicílio. Dissertação de mestrado. Faculdade de Saúde Pública, Universidade de São Paulo, São Paulo. 83p.

Pavlica Z, Petelin M, Juntes P, Erzen D \& Crossley DA (2008) Periodontal Disease Burden and Pathological Changes in Organs of Dogs. Journal of Veterinary Dentistry, 25:97-105.

Pihlstrom BL, Michalowicz BS \& Johnson NM (2005) Periodontal diseases. Lancet, 366:1809-1820.

Reynolds JJ \& Meikle MC (1997) Mechanisms of connective tissue matrix destruction in periodontitis. Periodontology 2000, 14:144-157.

Venturini MAFN (2006) Estudo retrospectivo de 3055 animais atendidos no ODONTOVET ${ }^{\circledR}$ durante 44 meses. Dissertação de mestrado. Universidade de São Paulo, São Paulo. 103p.

Venturini MAFA, Ferro DG, Correa Hl \& Gioso MA (2007) Doenças da cavidade oral atendidas no Centro Odontológico Veterinário durante 44 meses - estudo retrospectivo. Revista Nosso Clínico, 59:6-14.

Wiggs RB, Loprise H \& Mitchell PQ (1998) Oral and periodontal tissue. Maintenance, augmentation, rejuvenation and regeneration. Veterinary Clinics of North America: Small Animal Practice, 28:1165-1188. 